\title{
ASEET SOSIAL PENGEMBANGAN PARIWISATA PERDESAAN TANGGUH BENCANA BERKELANJUTAN
}

\author{
(Pengabdian Kepada Masyarakat melalui Pengembangan Desa Binaan di Desa Kalibening, \\ Kecamatan Dukun Kabupaten Magelang (Periode 2014-2018) \\ Muhamad Muhamad', Slamet Widiyanto \\ 1 Sekolah Pascasarjana Universitas Gadjah Mada Yogyakarta \\ ${ }^{2}$ Fakultas Biologi Universitas Gadjah Mada Yogyakarta \\ e-mail: drmuhammad@ugm.ac.id, e-mail: widy@ugm.ac.id
}

\begin{abstract}
ABSTRAK
Tujuan utama pengabdian kepada masyarakat untuk mengetahui modal aset sosial: mengetahui pengetahuan dan keterampilan yang dimiliki mengakibatkan tidak mampu mengenali potensi. Metode pelaksanaan lebih terfokus pada Focus Group Disscussion, quisioner dalam upaya menjaring tingkat partisipatif masyarakat. Pengabdian kepada masyarakat menggunakan rentang waktu 2014-2018 melalui skema desa binaan. Hasil pelaksanaan pengabdian mengetahui modal sosial $(3,0)$ : modal finansial $(3,3)$, modal alam $(4,0)$ dan modal manusia $(3,4)$, modal fisik $(2,6)$, sehingga modal yang dimiliki mempunyai potensi yang tinggi untuk pengembangan pariwisata perdesaan. Dampak hasil pelaksanaan, masyarakat setelah mengetahui modal asset sosial tinggi, masyarakat mengembangkan pariwisata tangguh bencana.
\end{abstract}

Kata Kunci: Desa Wisata, Tangguh Bencana, Asset Sosial

\section{PENDAHULUAN}

Tujuan yang terpenting dari pelaksanaan pengabdian kepada masyarakat (PKM) yaitu menekankan fokus pada upaya mengukur tingkat partisipasi masyarakat dalam pengembangan pariwisata perdesaan yang berkelanjutan. Tujuan program merupakan salah satu bentuk pengembangan yang basisnya adalah: potensi alam berupa daya tari wisata, aksesibilitas dan amenitas, selain itu modal sosial. Komponen komponen yang tersebut diatas merupakan dasar untuk pengembangan pariwisata berbasis masyarakat.
Beberapa fakta yang berkembang dan melatar belakangi dari tahun ketahun terutama pada pelaksanaan KKN antar semester dari tahun 2013 sampai dengan tahun 2018 mengindikasikan bahwa pelaksanaan Pengabdian Kepada Masyarakat (PKM) berlangsung secara terus menerus dan dari tahun ke tahun. Tematik yang dikembangkan akan satu persatu diurai untuk menemukan berbagai fakta yang berkembang sebagai indikator yang melatar belakangi pelaksanaan KKN dan skema Pengabdian Kepada Masyarakat di Desa Ekonomi, Sosial, dan Budaya 
Kalibening, Kecamatan Dukun Kabupaten Magelang.

Rentang waktu 2013-2014 program Kuliah Kerja Nyata (KKN) antar semester, tematik yang dikembangkan berupa aspek-aspek penanganan pasca bencana erupsi Merapi tahun 2010. Pemahaman terhadap konteks kewilayahan yang didasarkan terhadap fungsi Rencana Tata Ruang Wilayah (RTRW) merupakan Kawasan Rawan Bencana (KRB) di kabupaten Magelang. Sekaligus ploating pengembangan pariwisata alam dan budaya Gunung Merapi. Erupsi di tahun 2010 mengakibatkan kawasan Desa Kalibening pada khususnya dan Kecamatan Dukun pada umumnya telah berdampak secara masif.

Beberapa upaya yang dilakukan dalam pengembangan tematik dalam konteks kewilayahan adalah hal penting dan strategis dalam upaya mewujudkan pemahaman tentang potensi Kawasan Rawan Bencana dan pemberdayaan masyarakat di wilayah perdesaan. Keterlibatan dan upaya pihak lain melalui tema tahun 2013-2014 upaya yang dapat dilakukan antara lain: PKM UGM melalui KKN antar Semester, Bapedda Kabupaten Magelang, BLH (Badan Lingkungan Hidup), Basarnas dan BPBD kabupaten Magelang, Dinas Pariwisata, NGO asing dan relawan bencana dan para pemangku kepentingan yang lain. Indikator keberhasilan dalam periode tahun 2013/2014 KKN antar semester ini adalah terbentuknya village sister (desa bersaudara) antara desa Sidokarto dan Tanjung melalui perjanjian dan kesepakatan yang di inisiasi oleh KKN UGM dan BPBD Kabupaten Magelang. Persoalan dan permasalahan peristiwa bencana memiliki resiko ancaman bergantung akibat bahaya (hazard) kerentanan (vulnerability) dan ketahanan masyarakat. Kebencanaan ini memiliki berbagai sumber penyebab seperti yang dailami oleh masyarakat di desa Kalibening, Kecamatan Dukun Kabupaten Magelang, adanya bahaya erupsi Merapi yang terjadi pada tahun 2010. Tantangan dalam periode KKN 2013/2014 adalah sangat dibutuhkan pengambilan keputusan secara pasti dan secara stokastik dalam dua tahap yaitu sebelum dan sesudah bencana itu terjadi (Falasca, 2011)
Konsep yang dikembangkan dan tujuan yang dilakukan selama periode tahun 2017/2018 ini adalah: a) membuat peta dasar pijakan yang akurat bagi pelaksanaan program-program pengembangan desa binaan yang sesuai dengan kebutuhan wilayah pedesaan dalam konteks kewilayahan di tingkat Kabupaten Magelang; b).membangun kepedulian terhadap kebencanaan bagi para stake holder c) membangun tingkat kesadaran masyarakat pada upaya pemulihan (traumatik); d) membangun jejaring (konektifitas) antar perdesaan berupa village sister (desa bersaudara) yang berada di sekitarnya, e) memberdayakan masyarakat dan menyejahterakan masyarakat.

Periode dari tahun ke tahun dalam tulisan ini akan mengulas rentang waktu dari tahun 2014-2018 (periode antar semester) labih terfokus dan bertujuan pada upaya menggali potesi desa dan upaya membangun kembali kegiatan ekonomi masyarakat dalam upaya berkelanjutan. Potensi yang dikembangkan dari beberapa aspek seperti: aspek pemberdayaan masyarakat, pengembangan sistem informasi yang dikaitkan dengan pengembangan program melalui skema pengembangan Teknologi Tepat Guna (TTG), pengembangan pada potensi pada bidang perkebunan berupa salak pondoh dan tanaman hortikultura, pengembangan peternakan, identifkasi potensi daya tarik wisata, sosialisasi upaya pemulihan pasca erupsi dan lain lain. Rentang waktu merupakan kelanjuatan (time series) yang dilakukan dengan pemahamn terhadap potensi kompetensi dari peserta Kuliah Kerja Nyata yang terbagi dalam 4 kelompok (cluster) yaitu: kelompok sosial humaniora, kelompok sainstek, kelompok kesehatan, kelompok agro. Permasalahan utama dalam periode tahun 2017/2018 ini adalah upaya membangun masyarakat melalui Pemnfaatan Teknologi Tepat Guna melalui system informasi desa. Permasalahan utama dan tantangannya adalah masyarakat belum bisa mengakses teknologi informasi ini dan tidak mempunyai perangkat teknologi ini. Pemanfaatan Tenologi Informasi in bertujuan untuk menginput data penting terkait dengan situasi kondisi eksisting desa yang selanjutnya masyarakat bisa

$$
\text { Ekonomi, Sosial, dan Budaya }
$$


menginput data dam mengupdate data dan mengakses langsung.

Periode berikutnya tahun 2017-2018 (periode antar semester) pelaksanaan bersamaan dengan skema pengembangan desa binaan (Desbin) yaitu mengkombinasikan dan bersinergi antar program. Pelaksanaan terfokus menggali potensi desa secara komprehensif dan keberlanjutan program. Pada periode ini berhasil diidentifikasi permasalahan yang ada pada kelompok sasaran yaitu: upaya menggali potensi dan memulihkan masyarakat dalam fokus pemberdayaan dan peningkatan kapasitas masyarakat. Penggalian potensi desa adalah upaya membangun masyarakat untuk masyarakat (community base).

Bentuk pembangunan masyarakat perdesaan yang dapat dilakukan untuk menanggulangi kemiskinan salah satunya adalah meningkatkan kapasitas masyarakat melalui pemberdayaan masyarakat sehingga mampu mendefenisikan dan memenuhi kebutuhan masyarakat. Rendahnya keterampilan yang dimiliki masyarakat perdesaan mengakibatkan mereka tidak mampu mengenali apa yang dibutuhkan dalam meningkatkan taraf hidupnya. Skema pengembangan desa binaan dan Kuliah Kerja Nyata (KKN) periode 2017/2018 dilatar belakangi oleh pentingnya penyusunan dan pemetaan potensi desa desa wisata yang merupakan modal dasar bagi pengembangan tersebut. Alasan inilah yang merupakan urgensi terpenting yang segera untuk dilakukan, karena berbagai alasan penting, antara lain: 1) Mempunyai modal sosial antara lain: modal fisik, modal alam, modal finansial, modal sumber daya alam, modal sumber daya manusia, 2) Mempunyai inisiatif dan partisipasi yang tinggi didalam merespon pengembangan desa binaan melalui kepariwisataan khusunya pengembangan desa wisata binaan, 3) Kelompok sasaran memiliki karakteristik didalam merespon bencana (tangguh bencana) dan memiliki dua desa saudara, yaitu Desa Tanjung dan Desa Ngadikarto yang berada di kecamatan Muntilan. Kesepakatan desa saudara tersebut terjalin pada tahun 2011 yang ditandatangi oleh penandatanganan Memo of Understanding $(\mathrm{MoU})$ oleh ketiga kepala desa, 3) Posisi dan peran desa rintisan tangguh bencana merupakan respon terpenting di kawasan rawan bencana dan masyarakat telah mampu mengimplementasikannya secara berkelnajutan, 4) Posisi dan peran strategi kegiatan pariwisata di desa binaan merupakan bagian dari pengembangan wilayah secara terpadu didalam rangka pemberdayaan masyarakat, 5) Pengembangan melalui kegiatan wisata di desa binaan merupakan hal kontekstual terhadap inisiatif dari masyarakat sekaligus merespon UU No 16 tentang undang-undang perdesaan.

Terdapat poin dan tujuan penting dalam upaya pemulihan dalam upaya pemberdayaan masyarakat yaitu: menggali potensi modal sosial, identifikasi, pemetaan daya tarik wisata. Identifikasi, pemetaan daya tarik wisata adalah keterlibatan dalam mengembangkan potensi wisata (community base tourism) inilah yang menjadi fokus utama pengembangan. Pelaksanaan KKN antar semester tahun 2017/2018 telah mendapat dukungan penuh dari Direktorat Pengabdian Kepada Masyarakat Universitas Gadjah Mada (DPKM-UGM) melalui PPKM berbasis Pengembangan Desa Binaan. Selain itu, program ini juga diselenggarakan atas dukungan dari pemerintah Kabupaten Magelang dan perangkat Desa Kalibening, Kecamatan Dukun sehingga pihakpihak tersebut juga akan ikut memonitoring keberlangsungan program ini.

Konsep penyusunan identifikasi, inventarisasi dan pemetaan potensi Desa wisata Kalibening Kecamatan Dukun kabupaten Magelang, dalam rangka pemberdayaan masyarakat melalui pariwisata merupakan hal yang sangat penting dan strategis dalam upaya mewujudkan pemberdayaan masyarakat dan dan meningkatkan kesejahteraan masyarakat di wilayah perdesaan. Melalui Inventarisasi dan pemetaan potensi desa yang menekankan pada potensi dan daya tarik wisata diharapkan dapat menjadi dasar pijakan yang akurat bagi pelaksanaan program-program pengembangan

$$
\text { Ekonomi, Sosial, dan Budaya }
$$


yang sesuai dengan kebutuhan wilayah pedesaan.

Target kegiatan dalam DPKM UGM ini terutama pada pengembangan pariwisata yang memiliki karakter dan nilai strategis yang memberikan justifikasi kuat sebagai agen pengembangan/ pembangunan wilayah dan masyarakat. Kebutuhan pokok dalam konteks inventarisasi dan identifikasi pada KKN PPM dan pengembangan Desa Binaan tahun 2017/2018 menekankan local resource based industry; yaitu karakteristik industri pariwisata yang sangat ramah pada penyerapan sumber daya lokal serta sifatnya yang padat karya akan sangat efektif dalam menyerap tenaga kerja dan membuka peluang usaha di daerah.

Target kegiatan KKN PPM dan pengembangan Desa Binaan tahun 2017/2018 dapat memperoleh dan menguatkan karakter keterkaitan lintas sektor dan lintas skala usaha yang sangat tinggi, sehingga sektor pariwisata memiliki kemampuan yang sangat besar dalam menciptakan dampak ekonomi multi ganda bagi daerah dan masyarakat. Dari latar belakang di atas maka dapat ditarik kesimpulan dalam menentukan permasalahan dan persoalan sebagai berikut:

Tabel 1. Permasalahan, persoalan, tantangan atau kebutuhan masyarakat yang faktual dan aktual:

\begin{tabular}{|c|c|c|c|c|}
\hline Periode PKM & Tantangan & $\begin{array}{l}\text { Kebutuhan } \\
\text { masyarakat }\end{array}$ & Target Kegiatan & $\begin{array}{l}\text { Lembaga } \\
\text { terkait }\end{array}$ \\
\hline $2013 / 2014$ & $\begin{array}{l}\text { 1. Traumatik } \\
\text { masyarakat } \\
\text { terhadap } \\
\text { bencana erupsi } \\
\text { merapi } \\
\text { 2. Pemahaman dan } \\
\text { akselerasi desa } \\
\text { bersaudara } \\
\text { (village sister) }\end{array}$ & $\begin{array}{l}\text { 1. Pemulihan } \\
\text { pasca } \\
\text { bencana } \\
\text { erupsi } \\
\text { 2. Terbentuk } \\
\text { nya desa } \\
\text { bersaudara } \\
\text { untuk } \\
\text { bersinergi }\end{array}$ & $\begin{array}{l}\text { 1. Upaya } \\
\text { pemulihan } \\
\text { secara } \\
\text { psikologis } \\
\text { 2. Tingkat } \\
\text { keselamatan } \\
\text { masyarakat } \\
\text { dalam upaya } \\
\text { penanganan } \\
\text { pengungsi }\end{array}$ & $\begin{array}{l}\text { 1. PKM } \\
\text { UGM, } \\
\text { Dinas } \\
\text { kesehatan, } \\
\text { Basarnas, } \\
\text { BPBD kab. } \\
\text { 2. PKM } \\
\text { UGM, } \\
\text { Dinas } \\
\text { kesehatan, } \\
\text { Basarnas, } \\
\text { BPBD kab }\end{array}$ \\
\hline $2014 / 2015$ & $\begin{array}{l}\text { Pemberdayaan } \\
\text { masyarakat melalui } \\
\text { pariwisata }\end{array}$ & $\begin{array}{l}\text { Pemulihan } \\
\text { untuk } \\
\text { meningkatkan } \\
\text { ekonomi }\end{array}$ & \begin{tabular}{lr}
\multicolumn{2}{l}{ Teridentifikasi } \\
potensi & dan \\
daya & tarik \\
wisata &
\end{tabular} & $\begin{array}{l}\text { PKM UGM, } \\
\text { Dinas } \\
\text { kesehatan, }\end{array}$ \\
\hline $2015 / 2016$ & $\begin{array}{l}\text { 1. Siapkah } \\
\text { masyarakat } \\
\text { untuk } \\
\text { menentukan } \\
\text { arah } \\
\text { 2. Pemanfaatan } \\
\text { TTG basis TI }\end{array}$ & $\begin{array}{l}\text { 1. Secara } \\
\text { gradual } \\
\text { adanya } \\
\text { perubahan } \\
\text { signifikan } \\
\text { 2. Perhatian } \\
\text { kepada } \\
\text { seluruh } \\
\text { stake } \\
\text { holder }\end{array}$ & 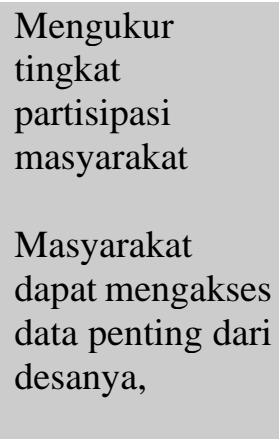 & $\begin{array}{ll}\text { 1. } & \text { PKM } \\
\text { UGM } \\
\text { 2. } \\
\text { PKM } \\
\text { UGM, } \\
\text { Dinas } \\
\text { kesehata } \\
\text { n, } \\
\text { Basarnas } \\
\text { BPBD } \\
\text { kab dan }\end{array}$ \\
\hline
\end{tabular}




\begin{tabular}{|c|c|c|c|c|}
\hline $2016 / 2017$ & $\begin{array}{l}\text { Siapkah dalam } \\
\text { peningkatan } \\
\text { kapasitas SDM }\end{array}$ & $\begin{array}{l}\text { Terbentuknya } \\
\text { Lembaga yang } \\
\text { diakui oleh } \\
\text { desa dan dinas } \\
\text { terkait }\end{array}$ & $\begin{array}{l}\text { Terbentuknya } \\
\text { Kelompok } \\
\text { Masyarakat } \\
\text { Sadar Wisata } \\
\text { (Pokdarwis) }\end{array}$ & $\begin{array}{l}\text { PKM UGM, } \\
\text { Pokdarwis } \\
\text { dan Dinas } \\
\text { pariwisata }\end{array}$ \\
\hline $2017 / 2018$ & $\begin{array}{l}\text { Terbentuk desa } \\
\text { wisata berbasis } \\
\text { pada alam dan } \\
\text { Tangguh bencana }\end{array}$ & $\begin{array}{l}\text { Pendeklarasian } \\
\text { desa wisata } \\
\text { yang berbasis } \\
\text { pada alam dan } \\
\text { Tangguh } \\
\text { bencana }\end{array}$ & $\begin{array}{l}\text { Aktifitas dan } \\
\text { kegiatan setelah } \\
\text { terbentuknya } \\
\text { desa wisata }\end{array}$ & $\begin{array}{l}\text { PKM UGM } \\
\text { dan Dinas } \\
\text { pariwisata } \\
\text { Kementrian } \\
\text { pariwisata. }\end{array}$ \\
\hline
\end{tabular}

Sumber: Analisis peneliti, 2019

Salah satu dimensi fungsi dan tujuan strategis sebagaimana disebutkan di atas adalah pada aspek modal sosial dan pemberdayaan masyarakat dala, mengatasi permasalahan, persoalan, tantangan atau kebutuhan masyarakat yang faktual dan aktual seperti pada tabel diatas. Pemberdayaan masyarakat pada dasarnya merupakan upaya untuk menciptakan atau meningkatkan kapasitas masyarakat baik secara individu maupun berkelompok dalam memecahkan berbagai persoalan terkait upaya peningkatan kualitas hidup, kemandirian dan kesejahteraannya. Pemberdayaan masyarakat dalam tagrt KKN PPM dan Pengembangan Desa Binaan memerlukan keterlibatan yang lebih besar dari perangkat pemerintah daerah serta berbagai pihak untuk memberikan kesempatan dan menjamin keberlanjutan berbagai hasil yang dicapai dalam upaya membangun pariwisata perdesaan yang berkelanjutan.

Tabel 2 Ketarkaitan produk wisata dan dampak langsung secara ikutan

\begin{tabular}{|c|c|c|}
\hline Dampak langsung & Dampak tak langsung & Dampak ikutan \\
\hline $\begin{array}{l}\text { Pokdarwis, Kelompok } \\
\text { masyarakat dan asosiasinya, } \\
\text { Perhotelan, Guide, Restoran, } \\
\text { destinasi, Perusahaan Airline/ } \\
\text { Angkutan, Galleri/ art shop, } \\
\text { Jasa keuangan (perbankan) }\end{array}$ & $\begin{array}{l}\text { Warung makan dan } \\
\text { restoran, perusahaan } \\
\text { perjalanan, destinasi , dsb, } \\
\text { Supir angkutan. Umum, } \\
\text { Pemerintah (pajak), } \\
\text { Pengrajin cinderamata } \\
\text { Pompa bensin, Penjual } \\
\text { sayuran, buah \& bahan } \\
\text { makanan,, Seniman iklan/ } \\
\text { Percetakan }\end{array}$ & $\begin{array}{l}\text { Petani sayuran, bunga dan } \\
\text { buah Peternak ayam, ikan } \\
\text { dan sapi, Penghasil bahan } \\
\text { baku kerajinan, sektor } \\
\text { industri \& perdagangan } \\
\text { Sektor agribisnis dan sektor } \\
\text { lain yang relevan }\end{array}$ \\
\hline
\end{tabular}

Sumber: Analisis peneliti, 2019

Masyarakat lokal serta institusiinstitusi lokal kemasyarakatan serta lembagalembaga non-pemerintah, merupakan faktor yang berperan menentukan pengembangan wilayah masing-masing sesuai dengan karakteristik pengembangannya. Oleh karena itu menurut Davidson, R, (1997) pendekatan didalam pengembangan masyarakat binaan

Ekonomi, Sosial, dan Budaya 
menggunakan konsep yang akan digunakan adalah Community Based Strategic Planning.

Pendekatan ini dilakukan dengan memandang wilayah sebagai suatu kesatuan ruang sosial (social space) sebagai suatu perwujudan dan lingkungan masyarakat, Muhamad. (2010) dan Lodewijk, Maha Neni (2013) . Penataan pemanfaatan ruang dan pengimplementasian ragam budaya dan tata nilai harus ditempatkan sebagai suatu variabel yang penting dalam mendukung pengembangan wilayah.dengan pendekatan Pengembangan masyarakat binaan ini diharapkan dapat menghindari kemungkinan terjadinya benturan sosial dan keterasingan dari kegiatan pembangunan serta kesenjangan wilayah yang berdampak negatif terhadap kinerja pertumbuhan wilayah maupun perkembangan sosial budaya masyarakat.

Mengingat hal tersebut, maka dalam rangka kegiatanpengabdian kepada masyarakat melalui desa binaan melalui pariwisata dilakukan secara terbuka, sehingga memungkinkan untuk melaksanakan haknya, yakni memberikan masukan berupa informasi, data, tanggapan, saran-saran dan lain sebagainya. Sehingga demikian, rencana yang tersusun akan lebih aspiratif dan dapat mewadahi berbagai kepentingan setiap lapisan masyarakat. Pengembangan berbasis kemasyarakatan dapat digambarkan dalam bagan berikut :

\section{METODE PELAKSANAAN}

Metode yang dikembangkan dalam kajian ini metode deskriptif kulitatif dan kuantitatif . Metode kualitatif dikembangkan untuk memetakan periodisasi pelaksanaan $\mathrm{KKN}$ apa saja yang pernah dilakukan dan belum dilaksanakan. Metode kuantitatif melihat dan mengkaji pemetaan secara sosial dengan mengukur peran masing-masing variabel tentang modal sarana (physical capital), Sumber daya manusia (human capital), quisioner modal keuangan (financial capital), Sumber daya alam (nature capital). $\begin{array}{ccr}\text { Salah satu metode lain } & \text { yang dilakukan } \\ \text { dalam pelaksanaan } & \text { KKN } & \text { PPM dan }\end{array}$ Pengembangangan desa binaan adalah metoda RRA dan action. Metode yang digunakan ini merupakan proses belajar yang intensif untuk memahami kondisi perdesaan, dilakukan berulang-ulang, dan cepat. Untuk itu diperlukan cara kerja yang khas, seperti tim kerja yang dilakukan mahasiswa dan Dosen pembimbing lapangan (DPL) KKN PPM yang bersifat multidisiplin, menggunakan sejumlah metode, cara, dan pemilihan teknik yang khusus, untuk meningkatkan pengertian atau pemahaman terhadap kondisi perdesaan. Metode dan dan Ccara kerja tersebut tersebut dipusatkan pada pemahaman pada tingkat komunitas lokal yang digabungkan dengan pengetahuan ilmiah. Komunikasi dan kerjasama diantara masyarakat desa dan KKN PPM UGM dan Pengembangan desa binaan merupakan unsur yang sangat penting, dalam kerangka untuk memahami masalah-masalah di perdesaan, seperti pada skema dibawah ini:

\section{Teknik Pengumpulan Data}

Hasil penelitian sangat ditentukan oleh teknik pengumpulan data yang digunakan. Data yang diperlukan dalam penelitian ini merupakan data primer dan data sekunder baik berupa data kualitatif maupun data kuantitatif. Teknik pengumpulan data yang digunakan dalam penelitian yaitu teknik wawancara, kuesioner atau angket, observasi, studi dokumentasi, studi literatur dan penelusuran data online. Data primer diperoleh melalui wawancara mendalam, kuesioner atau angket dan observasi lapangan. Data sekunder didapatkan dari berbagai sumber dan data yang diperoleh melalui studi dokumentasi, studi literatur dan penelurusan data online.

\section{Wawancara}

Wawancara merupakan teknik pengumpuan data secara lisan terhadap responden dengan menggunakan pedoman wawancara untuk melakukan tanya-jawab. Penggunaan wawancara dalam penelitian ini merupakan metode pelengkap untuk mencari informasi yang tidak dapat diperoleh dengan cara

$$
\text { Ekonomi, Sosial, dan Budaya }
$$


lain (Hadi, 1989: 193). Metode wawancara mendalam (in-deep interview) dilakukan secara terstruktur menggunakan recorder dan pedoman wawancara yang diajukan kepada informan kunci. Informan wawancara yang dipilih yaitu tokoh masyarakat, pemuda di lokasi KKN PPM.. Hasil wawancara diolah menurut indeks matriks dengan rekaman, transkrip, catatan lapangan dan membaca catatan, penomoran hingga penjelasan peneliti terhadap hasil transkrip yang diperoleh (Wengraf, 2006: 208-214). Cara ini akan memudahkan peneliti untuk menginterpretasi hasil penelitian kedalam pembahasan.

\section{Kuesioner (Angket)}

Teknik kuesioner dipilih untuk mengumpulkan informasi tentang variabel partisipasi masyarakat . Metode angket merupakan serangkaian daftar pertanyaan yang disusun secara sistematis untuk diisi oleh responden (Bungin, 2010: 123). Instrumen menggunakan format rating scale atau skala penilaian summated ratings (Likert) yang memungkinkan peneliti menggunakan kuesioner terukur. Alternatif respon pernyataan subjek menggunakan tipe interval dalam skala 5 sebagai berikut:

Tabel 3 Skala Likert interval 5 poin untuk masyarkat

\begin{tabular}{|c|c|c|c|c|c|}
\hline$( \pm) / 0$ & \multicolumn{5}{|c|}{ Skala } \\
\hline \multirow{7}{*}{ 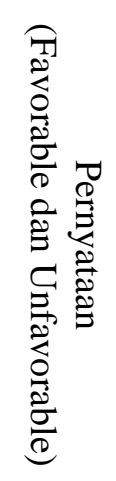 } & 1 & 2 & 3 & 4 & 5 \\
\hline & Tidak Pernah & Jarang & Kadang & Sering & Selalu \\
\hline & Tidak Ada & Sedikit & $\begin{array}{l}\text { Sebagian } \\
\text { Kecil }\end{array}$ & $\begin{array}{l}\text { Sebagian } \\
\text { Besar }\end{array}$ & Seluruh \\
\hline & Tidak Tahu & Kurang Tahu & Cukup Tahu & Tahu & Sangat Tahu \\
\hline & $\begin{array}{c}\text { Sangat Tidak } \\
\text { Sesuai }\end{array}$ & Tidak Sesuai & $\begin{array}{l}\text { Cukup } \\
\text { Sesuai }\end{array}$ & Sesuai & $\begin{array}{l}\text { Sangat } \\
\text { Sesuai }\end{array}$ \\
\hline & $\begin{array}{c}\text { Sangat Tidak } \\
\text { Bermanfaat }\end{array}$ & $\begin{array}{c}\text { Tidak } \\
\text { Bermanfaat }\end{array}$ & $\begin{array}{c}\text { Cukup } \\
\text { Bermanfaat }\end{array}$ & Bermanfaat & $\begin{array}{c}\text { Sangat } \\
\text { Bermanfaat }\end{array}$ \\
\hline & Tidak terlibat & $\begin{array}{c}\text { Karena } \\
\text { Paksaan }\end{array}$ & Ikut-ikutan & $\begin{array}{c}\text { Diajak } \\
\text { orang lain }\end{array}$ & $\begin{array}{c}\text { Kesadaran } \\
\text { sendiri }\end{array}$ \\
\hline
\end{tabular}

Sumber: Analisis ,2018

Metode quisioner berkaitan dengan quisioner tentang modal sarana (physical capital), Sumber daya manusia (human capital), quisioner modal keuangan (financial capital), Sumber daya alam (nature capital). Survey dilakukan secara langsung ke lapangan di lokasi KKN PPM UGM 2013-2018 untuk melihat kondisi aktual destinasi yang akan dikembangkan dan potensi masyarakat yang ada sebagai dasar penetapan pemetaan partisipatif yang sesuai. Penilaiannya akan dilakukan dengan menggunakan daftar periksa (check list) dimasing-masing komponen kepariwisataan alam.

\section{Indepth interview}

Indepth interview akan dilakukan dalam bentuk wawancara secara mendalam dengan tokoh-tokoh atau pelaku kunci yang terkait dengan isu/ permasalahan kelompok masyarakat. Sasaran indepth interview tersebut mencakup antara lain: aparat di lingkungan pemerintahan desa pemuda dan pemudi, dan industri agro atau unsur terkait lainnya. Kegiatan ini akan dilakukan di wilayah penelitian yaitu Desa Kalibening, Kecamatan Dukun, Kabupaten Magelan Jawa tengah sebagai lokasi kegiatan KKN PPM dan durasi waktu yang digunakan 2013-2018.

\section{ANALISIS DAN PEMBAHASAN}

Seperti yang diuraikan pada tahapan metode maka pendekatan dan metode partisipatif

$$
\text { Ekonomi, Sosial, dan Budaya }
$$


didalam mencari skala prioritas dengan cara mengurutan permasalahan-permasalahan dan masalah terberat yang dianggap krusial akan diprioritaskan dan di justifikasi di tingkat pertama (Azwar, 1995) dan (Baiquni , 2001). Periodisasi waktu yaitu mengurutkan aktifitas yang dilakukan yang merupakan rangkaian secara terpadu program pengabdian kepada masyarakat dan pemahaman terhadap kinerja partisipatif dengan urutan langkah dan metode yang dipergunakan antara lain:

\section{Tabel 4 langkah dan metode dalam analisis dan pembahasan}

\begin{tabular}{|c|c|}
\hline Metode/periode waktu & Kinerja partisipatif. \\
\hline $\begin{array}{l}\text { Focus: Pembentukan desa } \\
\text { bersaudara (village sister) }\end{array}$ & $\begin{array}{l}\text { - Pembentukan desa bersaudara (village sister) } \\
\text { - Pemulihan bencana dengan pembentukan OPRB } \\
\text { tingkat desa. } \\
\text { - Pemulihan secara psikologis }\end{array}$ \\
\hline KKN PPM tahun 2014/2015 & $\begin{array}{l}\text { - Pemanfaatan Teknologi Tepat Guna, Teknologi } \\
\text { Informasi Perdesaan (SID) }\end{array}$ \\
\hline $\begin{array}{lr}\text { Focus: } & \text { Pemanfaatan } \\
\text { Teknologi } & \text { Tepat Guna, } \\
\text { Teknologi } & \text { Informasi } \\
\text { Perdesaan (SID) }\end{array}$ & $\begin{array}{l}\text { - Masyarakat dan KKN mencari data penting pada tingkat } \\
\text { Desa } \\
\text { - Peningkatan kapasitas dalam penanganan } \\
\text { kebebncanaan dari BPBD Tingkat Kabupaten. }\end{array}$ \\
\hline KKN PPM tahun 2015/2016 & $\begin{array}{l}\text { - Pemanfaatan Teknologi Tepat Guna, Teknologi } \\
\text { Informasi Perdesaan (SID) }\end{array}$ \\
\hline $\begin{array}{l}\text { Focus: Pemanfaatan } \\
\text { Teknologi Tepat Guna, } \\
\text { Teknologi Informasi }\end{array}$ & $\begin{array}{l}\text { - Masyarakat dan KKN mencari data penting pada tingkat } \\
\text { Desa }\end{array}$ \\
\hline $\begin{array}{l}\text { PPM tahun 2015/2016 } \\
\text { Focus: } \quad \text { Identifikasi }\end{array}$ & $\begin{array}{l}\text { - Kegiatan pelatihan perumusan masalah yang bertujuan } \\
\text { untuk mengenali permasalahan secara detail } \\
\text { dikawasan. }\end{array}$ \\
\hline inven & $\begin{array}{l}\text { - Identifikasi dan inventarisasi potensi desa. } \\
\text { - Keterlibatan mahasiswa KKN PPM serta dosen } \\
\text { pembimbing lapangan (DPL) } \\
\text { - Pelatihan sertifikasi para pemandu wisata yang diikuti } \\
\text { oleh pemuda dan masyarakat penggiat wisata. } \\
\text { - Sertifikasi BNSP (Badan Nasional Sertifikasi) } \\
\text { kementrian pariwisata. }\end{array}$ \\
\hline KKN PPM tahun 2016/2017 & $\begin{array}{l}\text { - Kegiatan pelatihan pembuatan profiling yang bertujuan } \\
\text { untuk mengenali potensi daya tarik secara detail } \\
\text { dikawasan sebagai bagian langkah-langkah kecil dan }\end{array}$ \\
\hline $\begin{array}{l}\text { Focus: Guide book, Profill } \\
\text { desa }\end{array}$ & $\begin{array}{l}\text { sederhana dari sejumlah langkah besar yang harus } \\
\text { ditempuh oleh masyarakat sendiri upaya menjadikan } \\
\text { desa wisata. } \\
\text { - Masyarakat membuat profil desa wisata yang } \\
\text { berkonsentrasi di satu titik pengembangan }\end{array}$ \\
\hline
\end{tabular}

Ekonomi, Sosial, dan Budaya 
- Keterlibatan mahasiswa KKN PPM serta dosen pembimbing lapangan (DPL) dan masyarakat

- Fasilitasi oleh kementrian pariwisata republik Indonesia

KKN PPM tahun 2017/2018

- Masyarakat mempunyai inisiatif untuk kerja mandiri.

- Membuat masterplan partisipatif dan keterlibatan PPM Focus: Master Plan UGM, Dinas Pariwisata dan Masyarakat, Kelompok Partisipatif. Sadar Wisata (pokdarwis) desa wisata

Sumber: Analsisis, 2018

\section{Indikator Kinerja Partisipatif Pengembangan Program}

Pengembangan program desa binaan Perdesaan Berbasis masyarakat di Desa Kalibening, Kecamatan Dukun Kabupaten Magelang ini merencanakan program yang disesuaikan dengan program pemerintah desa dan pemerintah daerah yang bersangkutan serta berbasis masalah yang ada sesuai tema yang diangkat.

Program-program yang direncanakan pada dasarnya mengacu pemikiran jangka panjang yang digagas bersama masyarakat sehingga dapat berkelanjutan. Berikut kegiatan yang berkelanjutan yang dilakukan oleh masyarakat wilayah perdesaan di Desa Wisata Kalibening terutama prioritas di Dusun Gendungan Desa Kalibening sebagai lokasi program Pengembangan masyarakat binaan yang berlokasi di kawasan yang dekat dengan gunung berapi seperti Gunung Merapi memberikan ancaman yang menimbulkan bencana di wilayah lerengnya pada waktu-waktu tertentu.

\section{Aseet Sosial (Social Mapping) Pengembangan Pariwisata Perdesaan Tangguh Bencana Berkelanjutan}

Modal sosial (aseet social) merupakan modal dasar yang berkaitan dengan keterlibatan atau keikutsertaan suatu pihak dalam merespon atau menanggapi sesuatu. Verhangen menerjemahkan modal social sebagai bentuk khusus dari interaksi dan komunikasi yang berkaitan dengan pembangunan. Senada dengan pandangan tersebut, Bryant dan White (1989: 206) mengemukakan bahwa modal sosial merupakan proses kekuatan awal dari pelibatan diri masyarakat dalam menyusun suatu rencana dan melaksanakan proyek atau kegiatan.

Sampel Analisis yang dikembangkan dalam kajian ini dari masyarakat sebagai tokoh kunci antara lain: Kepala Desa kalibening, Kelompok sadar wisata Desa Wisata Gendungan, Penggiat wisata, dan masyarakat (nama dan identitas tidak di sebutkan), dengan penelitian sebagai berikut.

Tabel 5 Instrumen Mapping Modal sosial (social capital)

\begin{tabular}{ll}
\hline Mapping Aseet & \multicolumn{2}{c}{ Instrumen Mapping aseet } \\
\hline $\begin{array}{l}\text { Modal sosial } \\
\text { (social capital) }\end{array}$ & a) $\begin{array}{l}\text { Kebijakan/Peraturan di (Desa/Kelurahan) tentang } \\
\text { Penanggulangan Bencana/Pengurangan Risiko Bencana, } \\
\text { b) Intensitas pertemuan warga masyarakat (dalam kegiatan } \\
\text { Rapat RT, Arisan, Pengajian), }\end{array}$ \\
\hline
\end{tabular}

Ekonomi, Sosial, dan Budaya 
c) kegiatan Pokdarwis kaitannya dengan Penanggulangan Bencana/Pengurangan Risiko Bencana di desa

d) Kegiatan karang taruna kaitannya dengan Penanggulangan Bencana/Pengurangan Risiko Bencana di destinasi,

e) Kegiatan Pengelola Wisata kaitannya dengan Penanggulangan Bencana/Pengurangan Risiko Bencana di destinasi

Sumber: Analisis, 2018

Tabel 6 Instrumen Mapping Modal Sarana (physical capital)

\begin{tabular}{|c|c|}
\hline Mapping Aseet & Instrumen Mapping aseet \\
\hline $\begin{array}{l}\text { Modal Sarana } \\
\text { (physical } \\
\text { capital) }\end{array}$ & $\begin{array}{l}\text { a) Jalan dan kelengkapan jalan (petunjuk jalan, penerangan } \\
\text { jalan) } \\
\text { b) Jalur Wisata dan kelengkapannya (petunjuk arah, pagar } \\
\text { pengaman, penerangan jalan), } \\
\text { c) Petunjuk lokasi rawan bencana (petunjuk arah, rambu } \\
\text { bahaya) } \\
\text { d) Alat keselamatan (P3K, Alat Pelindung Diri, Radio } \\
\text { Komunikasi). }\end{array}$ \\
\hline
\end{tabular}

Sumber: Analisis, 2018
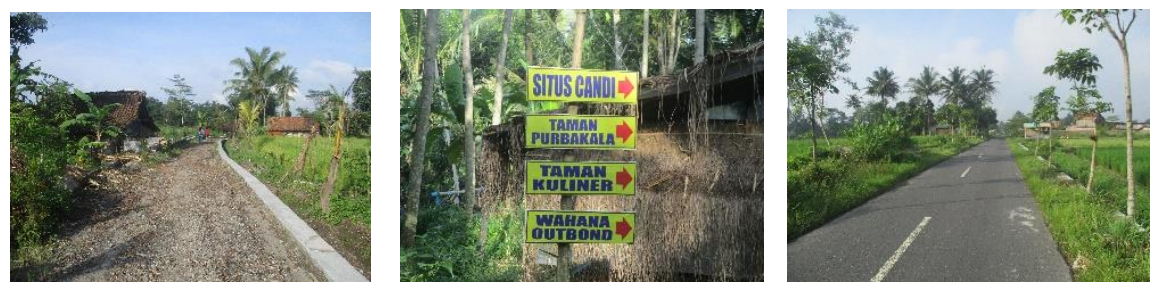

Gambar 3 Infrastruktur jalan sebagai modal fisik di desa Kalibening.

Sumber; dokumentasi, 2018

Tabel 7 Instrumen Mapping Modal Sumber daya manusia (human capital)

Mapping Aseet Instrumen Mapping aseet




\begin{tabular}{|c|c|c|}
\hline $\begin{array}{l}\text { Sumber daya } \\
\text { manusia (human } \\
\text { capital) }\end{array}$ & b) & $\begin{array}{l}\text { Pemahaman dan Kemampuan mengenai } \\
\text { kewilayahan/destinasi, Pemahaman dan Kemampuan } \\
\text { mengenai potensi bencana yang ada di destinasi. } \\
\text { Pemahaman dan Kemampuan mengenai mitigasi bencana } \\
\text { yang ada di destinasi (sebelum, saat, dan sesudah terjadi } \\
\text { bencana), } \\
\text { Pemahaman dan Kemampuan dalam membina hubungan } \\
\text { dengan para stake holder sebagai mitra. } \\
\text { Pemahaman dan Kemampuan mengenai Evakuasi pada } \\
\text { saat terjadi bencana (kecelakaan). }\end{array}$ \\
\hline
\end{tabular}

Sumber: Analisis, 2018

Tabel 8 Instrumen Mapping Modal Keuangan (financial capital)

\begin{tabular}{ll}
\hline Mapping Aseet & \multicolumn{2}{c}{ Instrumen Mapping aseet } \\
\hline $\begin{array}{l}\text { modal keuangan } \\
\text { (financial }\end{array}$ & a) Ketersediaan Dana Penanggulangan Bencana., \\
capital) & b) Ketersediaan Dana Pertolongan Pertama Pada Kecelakaan \\
& (P3K) untuk pengunjung, \\
& c) Ketersediaan Dana untuk respon kecelakaan/bencana \\
& (ambulans, paramedis, penyelamatan) \\
& d) Ketersediaan Dana untuk pasca kecelakaan/bencana \\
& (asuransi, pengobatan). \\
&
\end{tabular}

Sumber: Analisis, 2018
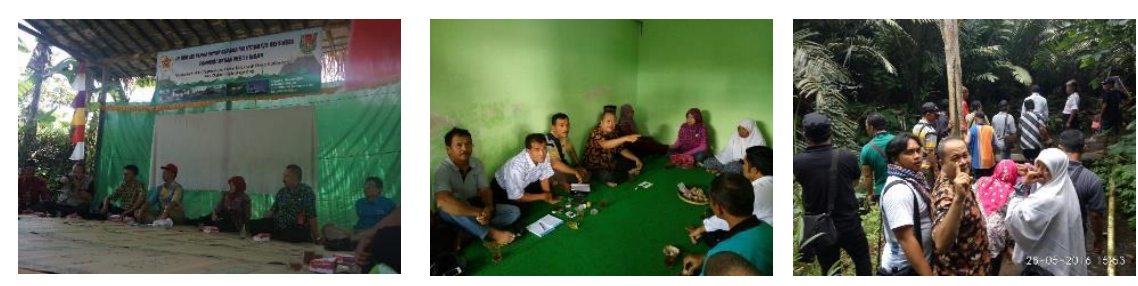

Gambar 4. Musyawarah dan mufakat proses pengambilan keputusan

Sumber dokumentasi : 2018

Tabel 9 Instrumen Mapping Modal Sumber Daya Alam (nature capital)

\begin{tabular}{ll}
\hline Mapping Aseet & Instrumen Mapping aseet \\
\hline & Ekonomi, Sosial, dan Budaya
\end{tabular}




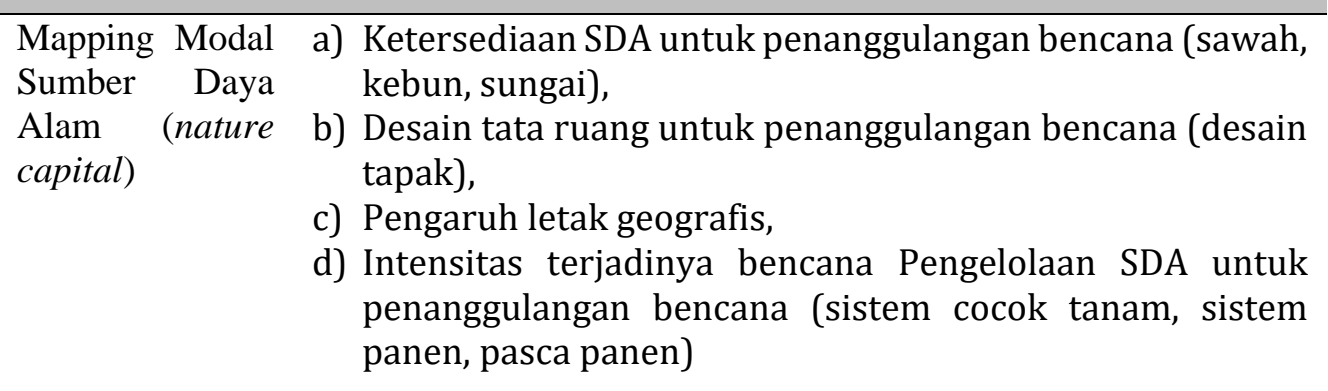

Sumber: Analisis, 2018
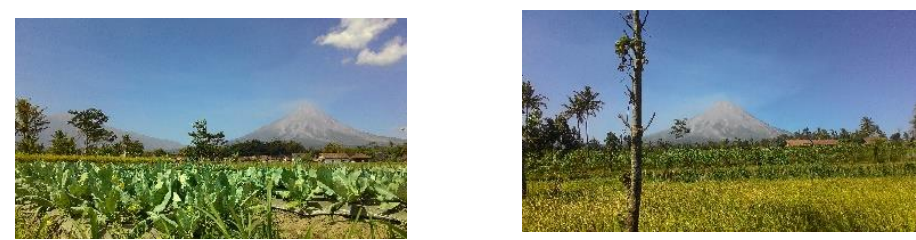

Gambar 5. Lanskap dan (view) yang menarik merupkan Modal Sumber Daya Alam Sumber: Dokumentasi pribadi, 2018

Tabel 10 Hasil Penilaian Aseet Sosial (Social Mapping) Pengembangan Pariwisata Perdesaan Tangguh Bencana Berkelanjutan

\begin{tabular}{|c|c|c|c|c|c|}
\hline \begin{tabular}{c} 
MODAL \} \text { NAMA } $\\
{\text { RESPONDEN }}$ & $A$ & $B$ & $C$ & $D$ & $A V E R A G E$ \\
\hline Modal sosial & 2,3 & 2,5 & 3,3 & 3,7 & 3,0 \\
\hline Modal finansial & 3,3 & 3,5 & 3,3 & 2,9 & 3,3 \\
\hline Modal fisik & 2,5 & 2,3 & 2,5 & 2,9 & 2,6 \\
\hline $\begin{array}{l}\text { Modal sumber daya } \\
\text { manusia }\end{array}$ & 3,3 & 3,3 & 3,5 & 3,5 & 3,4 \\
\hline $\begin{array}{l}\text { Modal sumber daya } \\
\text { alam }\end{array}$ & 3,7 & 3,9 & 3,6 & 4,7 & 4,0 \\
\hline
\end{tabular}
\end{tabular}

Sumber: Analisis, 20178

Hasil penilaian aseet sosial (Social Mapping) dari 10 responden terpenting tentang pengembangan pariwisata perdesaan tangguh bencana yang mempunyai nilai terbesar pada asset sumber daya alam, kekayaan sumber daya alam terkait ketersediaan SDA untuk penanggulangan bencana (sawah, kebun, 
sungai) dan adanya rencana tapak (titik kumpul) dan desain tata ruang untuk penanggulangan bencana. Nilai terbesar selanjutnya terletak pada SDM (sumber daya manusia) yang disebabkan adanya pemahaman dan kemampuan mengenai kewilayahan/destinasi, pemahaman dan kemampuan mengenai potensi bencana yang ada di destinasi wisata. Diagram pada gambar 2 berupa pentagram memperlihatkan posisi kuadran

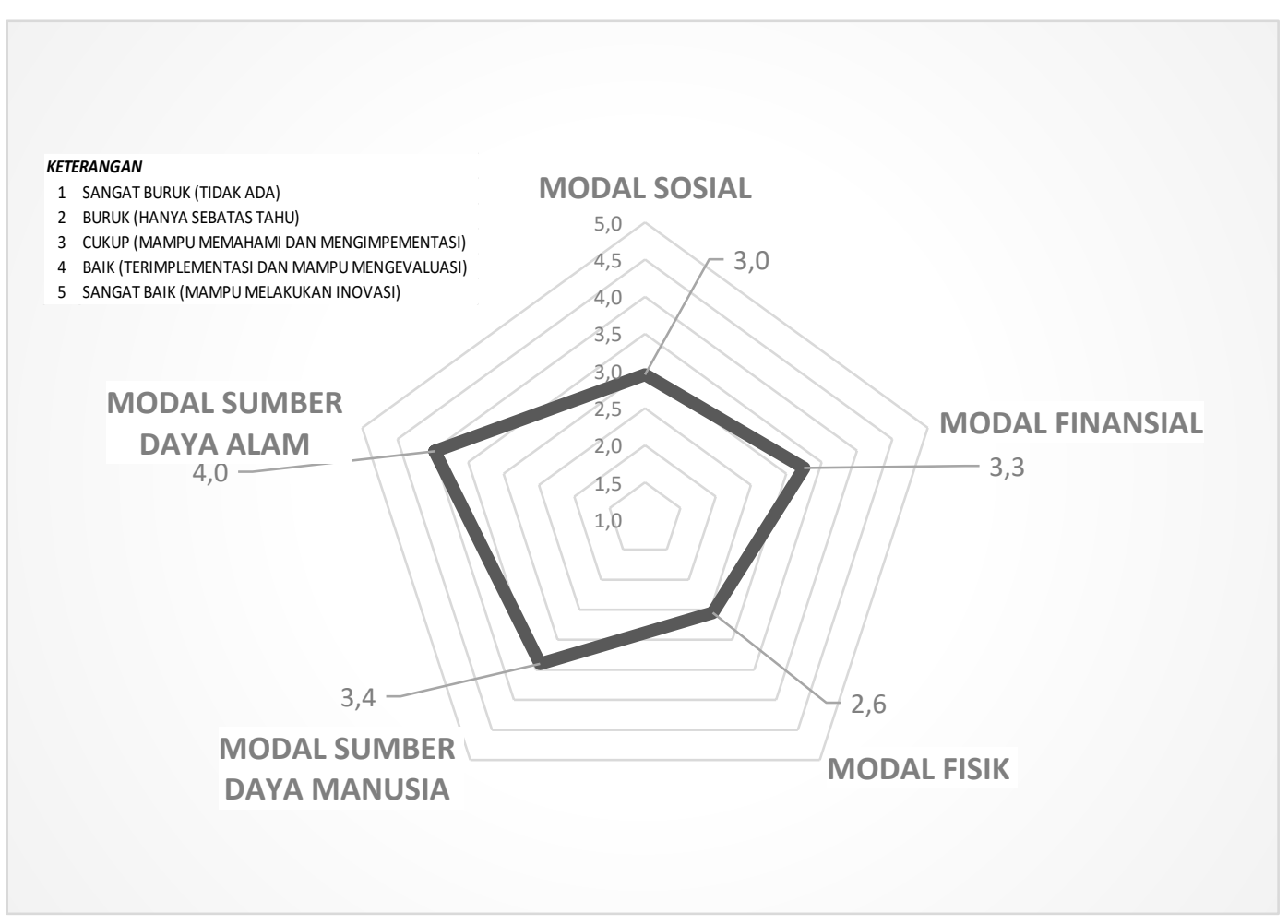
pada masingmasing lokasi mapping.

Gambar.6. Pentagram berdasarkan Asset mapping di Desa Kalibening.

Sumber: Analisis, 2018

Kemitraan yang terjalin antar pemangku kepentingan (stakeholder) yang berada pada mapping SDM merupakan nilai terpenting sebagai kemitraan yang juga merupakan bentuk jejaring sosial yang kuat baik secara internal maupun eksternal. Pengembangan kemitraan kedalam (internal) merupakan jejaring kerjasama antara pemerintah desa dengan masyarakat di desa Kalibening baik secara personal maupun kelompok. Sementara itu, kemitraan keluar (eksternal) merupakan kemitraan yang dilakukan dengan berbagai pihak terkait (stake holder).

Salah satu modal sosial dalam pengembangan kemitraan kedalam (internal) merupakan jejaring kerjasama antara pemerintah desa dengan masyarakat baik secara personal maupun kelompok, kemitraan keluar (eksternal) merupakan kemitraan yang dilakukan dengan berbagai pihak terkait (stake holder). Hasil mapping sosial ini menjadikan landasan yang kuat sebagai kekuatan mandiri masyarakat di dalam menjalankan program-program secara berkelanjutan. Program-program yang berkelanjutan yang didampingi oleh perguruan tinggi melalui program pelaksanaan pengabdian kepada masyarakat akan mempunyai pedoman penting dalam melakukan analisis terhadap potensi terutama modal sosial. 


\section{Kesimpulan}

1. Pelaksanaan KKN dan Pengembangan Desa binaan adalah bagian dari modal sosial (aseet social) yang merupakan modal dasar yang berkaitan dengan keterlibatan atau keikutsertaan suatu pihak dalam merespon atau menanggapi bentuk khusus dari interaksi dan komunikasi yang berkaitan dengan pembangunan

2. Modal sosial dalam pelaksanaan KKN PPM dan Pengembangan Desa Binaan adalah sebagai proses kekuatan institusional untuk berkomunikasi antara mahasiswa KKN dan pelibatan diri masyarakat dalam menyusun suatu rencana dan melaksanakan proyek atau kegiatan.

3. Pengembangan kemitraan kedalam (internal) merupakan jejaring kerjasama antara pemerintah desa dengan masyarakat di desa Kalibening baik secara personal maupun kelompok, kemitraan keluar (eksternal) merupakan kemitraan yang dilakukan dengan berbagai pihak terkait (stake holder).

4. Hasil penilaian aseet sosial (Social Mapping) dari 5 responden terpenting tentang pengembangan pariwisata perdesaan tangguh bencana berkelanjutan yang mempunyai nilai terbesar pada asset sumber daya alam, kekayaan sumber daya alam terkait ketersediaan SDA

5. Keberlanjutan program akan dilaksanakan oleh kemampuan mandiri dari masyarakat yang didukung oleh Perguruan Tinggi dan Kelompok Swadaya Masyarakat lainnya Saran dan Rekomendasi

1. Modal sosial (aseet social) yang merupakan modal dasar yang berkaitan dengan keterlibatan atau keikutsertaan masyarakat dalam merespon atau menanggapi terhadap potensi yang dimiliki. Seluruh potensi yang dimilki merupakan asset terpenting bagi Desa dalam menerapkan konsep pembangunan berkelanjutan.

2. Masyarakat desa Kalibening direkomendasikan sebagai desa yang mempunyai tingkat ketahanan terhadap bencana merapi dan desa yang mampu merespon bencana melalui mitigasi bencana yang merupakan asset dan modal terpenting.

3. Direkomendasikan menjadi desa yang mempunyai kemandirian terhadap kebencanaan dan kemandirian didalam pengelolaan kebencanaan. 


\section{Daftar Pustaka}

Arikunto, Suharsimi, 2010, Prosedur Penelitian: Studi Pendekatan Praktik, Jakarta: Rineka Cipta.

Azwar, S., 1995, Sikap Manusia Teori dan Pengukurannya, Yogyakata, Liberty.

Birkeland, C., 1983, Influences of Topography of Nearby Land Masses in Combination with Local water Movement Patterns on the nature of Nearshore Marine Communities, Productivity and Processes in Island Marine Ecosystem. UNESCO Report in Marine Science No. 27 Dunedine, page: 16-31

Bryant, Coralie dan Louise G. White, 1989, Managemen Pembangunan untuk Negara Berkembang, Penerjemah Rusyanto L. Simatupang, Jakarta: Penerbit LP3ES

Bungin, Burhan. 2007. Penelitian Kualitatif. Jakarta : Prenada Media Group

Davidson, R, 1997 An Urban Earthquake Disaster Risk Indeks. Ph.D Thesis, Deapartement of Civil Engineering, Stanford Univesity, USA, California, USA

Lawang, R.M.Z, 2005. Kapital Sosial: Dalam Perspektif Sosiologik Suatu Pengantar. Jakarta: FISIP UI Press.
Muhamad, Fandeli Chafid (2009), Prinsip-prinsip Dasar Mengkonservasi Lanskap, Gadjah Mada University Press, Yogyakarata.

Muhamad. (2010), Kepariwisataan Berkelanjutan di Wilayah Yogyakarta Utara Setelah Erupsi 2010, (Interaksi Masyarakat di dalam Pengelolaan Lingkungan dan Kepariwisataan Alam), Disertasi Sekolah Pascasarjana Universitas Gadjah Mada Yogyakarta, Tidak diTerbitkan dan Tidak di Publikasikan, Yogyakarta.

Muhamad. (2014), Lanskap

Kepariwisataan Alam di kawasan konservasi, Sekolah Pascasarjana UGM, Yogyakarata

Britha. 1999. Metode Penelitian Partisipatoris Upaya-Upaya Pemberdayaan Jakarta. Yayasan Obor Indonesia

Maha Neni Lodewijk, ), (2013) Participatory Rural Appraisal, Pendekatan dan Metode Partisipatif Dalam Pembangunan Masyarakat, Bandung

Nasution, S. 1996. Metode Penelitian Naturalistik-Kualitatif. Bandung : Tarsito.

Setyawan. B., Rahmi, D.H., Mitchell, B., (2000), Pengelolaan Sumberdaya dan Lingkungan Hidup, Gadjah Mada University Press, Yogyakarta. 